ISSN 1392-3196 / e-ISSN 2335-8947

Zemdirbyste-Agriculture, vol. 104, No. 1 (2017), p. 23-30

DOI 10.13080/z-a.2017.104.004

\title{
Genetic diversity of einkorn wheat (Triticum boeoticum Boiss.) accessions from the central Zagros Mountains
}

\author{
Behnaz SEIFOLAHPOUR, Sohbat BAHRAMINEJAD, Kianoosh CHEGHAMIRZA \\ Razi University \\ Kermanshah, Iran \\ E-mail: sohbah72@hotmail.com
}

\begin{abstract}
Genetic resources are the valuable natural resources and national wealth in each country. The wild relatives of wheat, especially diploid species have useful traits for the wheat breeding. To study the genetic variation of wild einkorn wheat (Triticum boeoticum Boiss.) populations based on the morphological, agronomical and phenological traits, an experiment was conducted on 252 collected samples from central Zagros Mountains with six cultivars as controls in Research Farm of Razi University, Kermanshah, Iran during 2013-2014. The seeds of the samples and control cultivars were sown based on an augmented randomized complete block design in seven replicates. According to the analysis of variance, there was high variation among the samples. The population $\mathrm{G}$ collected from Kamyaran location showed higher amounts than average for the spike length, peduncle length, plant height and thousand kernel weight. The results of correlation showed that a thousand kernel weight had a highly significant positive correlation with the peduncle length, the plant height and the awn length. The cluster analysis classified the accessions and controls in five groups with distinct properties. The classification of the accessions using cluster analysis did not match with their geographical distribution. The accessions in the first group had the short kernel filling period; the accessions in the second group were late-maturing ones, the accessions in the third one had the highest peduncle length and plant height, the genotypes in the fourth group had early-maturing accessions with the lowest plant height and peduncle length and finally the accessions in the last group had the lowest number of kernels per spike and spike length.
\end{abstract}

Key words: augmented design, genetic resources, wild relatives.

\section{Introduction}

The genus Triticum is one of the most important genera in the tribe Triticeae and has been the focal point of many biosystematics studies. Four basic genomes, A, $\mathrm{B}, \mathrm{D}$ and $\mathrm{G}$, are involved in the genomic constitution of all Triticum species (Lilienfeld, Kihara, 1934). The ancestral diploid species of A, B and D genome diverged from a common ancestor about three million years ago (Gill et al., 2004). The primary habitats of the wheat ancestors are situated in the northern and eastern parts of the Fertile Crescent and the modern wheat cultivars were evolved from their ancestors which mostly were distributed in these areas (Harlan, Zohary, 1966; Derakhshani et al., 2013). Einkorn (Triticum monococcum $\mathrm{L}$. $)(2 \mathrm{n}=2 \mathrm{x}=14$, nuclear genome constitution AA) is the earliest species of cultivated wheat that was domesticated from its wild progenitor, Triticum boeoticum Boiss. (Harlan, Zohary, 1966).

Wheat landraces represent an important source of genetic variation that can be used to improve the commercial varieties by introducing new alleles or combination of genes (Ciaffi et al., 1992). Moreover, the wild relatives of bread wheat are known to be important sources of traits for the wheat genetic improvement. The wild relatives of crop plants contain rich gene pools which are the best hope for crop improvement in future breeding programs (Plucknett et al., 1987). Wild and progenitors species of Triticum L. and Aegilops L. provide a useful source of new accessible genetic variation for wheat improvement including tolerance against abiotic (drought, cold, heat, salinity and herbicides) and biotic (pathogens, parasites and competitors) stresses. Dempewolf et al. (2014) explained a project entitled "Adapting Agriculture to Climate Change" and stated that domestication has led to reducing crop genetic diversity which it, along with climate change could make big challenges for plant breeders and farmers and could threaten the world's food security. Therefore, they suggest collecting crop wild relatives, conserving, evaluating them for useful and needed traits and making the results widely available to overcome the challenges faced the future of agriculture. The key importance of crop wild relatives to help adaptation to climate change is well described by Guarino and Lobell (2011). Valkoun (2001) stated that wheat wild progenitors are native to semi-arid regions of West and Central Asia. Therefore, they are well adapted to different stresses which are frequent in all regions with year-to-

Please use the following format when citing the article:

Seifolahpour B., Bahraminejad S., Cheghamirza K. 2017. Genetic diversity of einkorn wheat (Triticum boeoticum Boiss.) accessions from the central Zagros Mountains. Zemdirbyste-Agriculture, 104 (1): 23-30 DOI 10.13080/z-a.2017.104.004 
year climatic fluctuations. Hence, they may be suitable to utilize the rich indigenous genetic diversity of wheat wild diploid progenitors in wheat breeding for stress tolerance, plant productivity, yield stability and adaptation.

Little information is available regarding the genetic variation in the wild wheat relatives from Iran. Iran is known as a main centre of distribution of wild wheat. Iran especially is not only one of the main sites of domestication of common and emmer wheat but also a main centre of distribution of wild wheat genotypes (Kimber, Feldman, 1987). It is supposed that the populations of $T$. boeoticum in the western part of Iran contains high levels of genetic diversity and may provide significant information regarding their potential for breeding purposes. Salimi et al. (2005) collected and studied 14 populations of $T$. boeoticum, mainly from the west of Iran, in order to evaluate genetic diversity based on different agronomical traits. They reported the existence of two A-genome donor species, i.e. T. boeoticum and T. monococcum, in Iranian flora.

Since the central Zagros Mountains located in the west of Iran are among one of the main habitats of wild wheat accessions, they are ideal locations to search for desirable genes in order to transfer to cultivated wheat.
Therefore, the aim of this study is to look for the genetic diversity of the valuable traits in the wild einkorn wheat and make the data available to breeders to use them in the future breeding programs.

\section{Materials and methods}

In order to evaluate the genetic diversity and relationships among the morphological, agronomical and phenological traits in the populations of the wild diploid einkorn, an experiment was conducted at the Research Farm of the Campus of Agriculture and Natural Resources, Razi University, Kermanshah, Iran during 2013-2014 cropping season. The characteristics of the Research Farm is latitude $34^{\circ} 21^{\prime} \mathrm{N}$, longitude $47^{\circ} 9^{\prime} \mathrm{E}$, altitude $1319 \mathrm{~m}$ a.s.l., clay soil texture and about 379.3 $\mathrm{mm}$ average annual precipitation.

Plant materials. Plant materials which include 252 samples from sixteen einkorn wheat (Triticum boeoticum Boiss.) populations collected from central Zagros Mountains including Kermanshah, Ilam and Kurdistan province (Fig. 1) were kindly provided by M. M. Poursiahbidi.

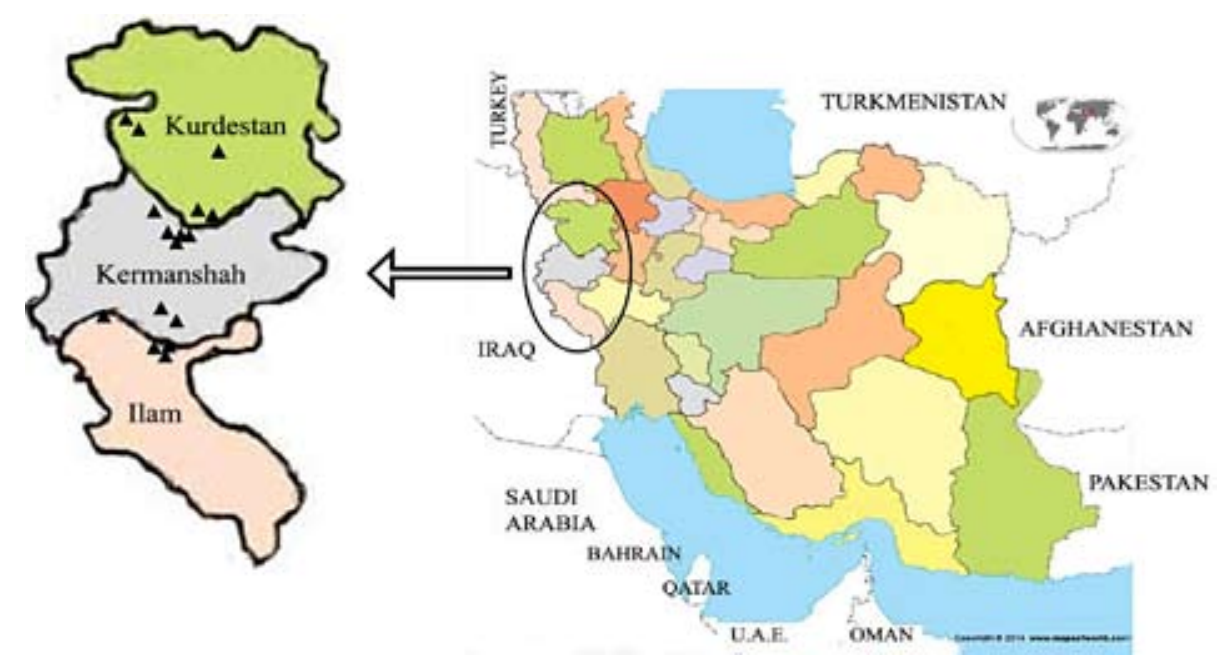

Figure 1. Map of Iran showing the collection site of the 252 accessions of Triticum boeoticum

Six controls namely three durum and three bread wheat cultivars were added to the experiment. Details of the plant materials are shown in Table 1 .

Experimental design. Seeds were sown in an augmented design experiment. In this design, the seeds of the samples were sown in seven blocks as one replicate. The seeds of the six control cultivars were sown randomly in seven blocks to provide an indication of the experimental error. Therefore, the effect of the blocks will be evaluated and the trait values will be corrected. The control cultivars were assessed in a randomized complete block design. Sowing was performed by hand at three row plots, in $1.50 \mathrm{~m}$ length and $0.50 \mathrm{~m}$ row spacing. Chemical fertilizers, herbicides and pesticides were not used. At full physiological maturity, one middle row of each plots was harvested to determine morphological and agronomical traits. The correction of data was only performed for those traits that the effect of blocks was significant in the analysis of variance. Therefore, all the next statistical analyses were performed using corrected data.
Studied traits. Different recorded morphological, agronomical and phenological traits are including: spike length (SL), cm, awn length (AL), cm, peduncle length $(\mathrm{PL}), \mathrm{cm}$, plant height (Phe), $\mathrm{cm}$, peduncle length/plant height (PL/Phe), number of spikelets per spike (NSPS), number of kernels per spike (NKPS), thousand kernel weight (TKW), g, days to stem elongation (DSE), days to booting (DB), days to heading (DH), days to anthesis (DA), days to physiological maturity (DPM) and kernel filling period (KFP).

Statistical analysis. Analysis of variance was performed using SAS 9.1. The correlation and the cluster analysis were carried out using SPSS, version 16 and SYSTAT, version 13 , respectively.

\section{Results}

Analysis of variance for control cultivars. The results of the analysis of variance showed highly significant differences among cultivars for all the studied traits, except days to stem elongation and days to heading (Table 2). 
Table 1. The wheat wild relatives (Triticum boeoticum) and control cultivars used for diversity study

\begin{tabular}{|c|c|c|c|c|c|c|c|c|}
\hline Species & Location & Longitude & Latitude & $\begin{array}{l}\text { Height } \\
\mathrm{m}\end{array}$ & $\begin{array}{l}\text { Geno- } \\
\text { me }\end{array}$ & $\begin{array}{l}\text { Growing } \\
\text { status }\end{array}$ & Origin & Symbol \\
\hline T. boeoticum & $\begin{array}{c}\text { Ilam, } \\
\text { Shirvan } \\
\text { Chardavol }\end{array}$ & $33^{\circ} 54.949^{\prime} \mathrm{N}$ & $46^{\circ} 22.674^{\prime} \mathrm{E}$ & 1310 & A & wild & West Iran & A1-A10 \\
\hline T. boeoticum & $\begin{array}{c}\text { Ilam, } \\
\text { Shirvan } \\
\text { Chardavol }\end{array}$ & $33^{\circ} 42.655^{\prime} \mathrm{N}$ & $46^{\circ} 31.557^{\prime} \mathrm{E}$ & 1258 & A & wild & West Iran & $\mathrm{C} 1-\mathrm{C} 10$ \\
\hline T. boeoticum & Kermanshah & $33^{\circ} 50.076^{\prime} \mathrm{N}$ & $46^{\circ} 43.740^{\prime} \mathrm{E}$ & 1245 & A & wild & West Iran & D1-D10 \\
\hline T. boeoticum & Kermanshah & $34^{\circ} 15.106^{\prime} \mathrm{N}$ & $46^{\circ} 42.917^{\prime} \mathrm{E}$ & 1354 & A & wild & West Iran & E1-E12 \\
\hline T. boeoticum & Kamyaran & $34^{\circ} 43.336^{\prime} \mathrm{N}$ & $46^{\circ} 53.475^{\prime} \mathrm{E}$ & 1408 & A & wild & West Iran & F1-F15 \\
\hline T. boeoticum & Kamyaran & $34^{\circ} 59434^{\prime} \mathrm{N}$ & $46^{\circ} 57.863^{\prime} \mathrm{E}$ & 1381 & A & wild & West Iran & G1-G15 \\
\hline T. boeoticum & Ravansar & $34^{\circ} 46.987^{\prime} \mathrm{N}$ & $46^{\circ} 47.233^{\prime} \mathrm{E}$ & 1591 & A & wild & West Iran & H1-H20 \\
\hline T. boeoticum & $\begin{array}{c}\text { Ilam, } \\
\text { Shirvan } \\
\text { Chardavol }\end{array}$ & $33^{\circ} 56.434^{\prime} \mathrm{N}$ & $46^{\circ} 16.993^{\prime} \mathrm{E}$ & 1193 & A & wild & West Iran & I1-I20 \\
\hline T. boeoticum & Eivan & $33^{\circ} 51.613^{\prime} \mathrm{N}$ & $46^{\circ} 15.564^{\prime} \mathrm{E}$ & 1113 & A & wild & West Iran & J1-J15 \\
\hline T. boeoticum & Javanrod & $34^{\circ} 48.013^{\prime} \mathrm{N}$ & $46^{\circ} 30.699^{\prime} \mathrm{E}$ & 1525 & A & wild & West Iran & $\mathrm{K} 1-\mathrm{K} 20$ \\
\hline T. boeoticum & Ravansar & $34^{\circ} 39.089^{\prime} \mathrm{N}$ & $46^{\circ} 42.022^{\prime} \mathrm{E}$ & 1397 & A & wild & West Iran & M1-M10 \\
\hline T. boeoticum & Ravansar & $34^{\circ} 33.480^{\prime} \mathrm{N}$ & $46^{\circ} 47.442^{\prime} \mathrm{E}$ & 1302 & A & wild & West Iran & N1-N20 \\
\hline T. boeoticum & Kermanshah & $34^{\circ} 26.910^{\prime} \mathrm{N}$ & $47^{\circ} 01.006^{\prime} \mathrm{E}$ & 1368 & A & wild & West Iran & P1-P10 \\
\hline T. boeoticum & Marivan & $35^{\circ} 36.480^{\prime} \mathrm{N}$ & $46^{\circ} 01.412^{\prime} \mathrm{E}$ & 1355 & A & wild & West Iran & R1-R5 \\
\hline T. boeoticum & Sanandaj & $35^{\circ} 22.572^{\prime} \mathrm{N}$ & $46^{\circ} 16.137^{\prime} \mathrm{E}$ & 1283 & A & wild & West Iran & $\mathrm{S} 1-\mathrm{S} 40$ \\
\hline T. boeoticum & Sanandaj & $35^{\circ} 1754.4^{\prime} \mathrm{N}$ & $46^{\circ} 58.453^{\prime} \mathrm{E}$ & 1662 & A & wild & West Iran & $\mathrm{T} 1-\mathrm{T} 20$ \\
\hline T. durum cv. Saji & Kermanshah & & & - & $\mathrm{AB}$ & durum wheat & Iran, DARSI & - \\
\hline T. durum cv. Zardak & Kermanshah & & & - & $\mathrm{AB}$ & $\begin{array}{l}\text { local durum } \\
\text { wheat }\end{array}$ & Iran & - \\
\hline T. durum cv. Dehdasht & Ilam & & & - & $\mathrm{AB}$ & durum wheat & Iran, Ilam & - \\
\hline T. aestivum cv. Rijaw & Kermanshah & & & - & $\mathrm{ABD}$ & bread wheat & Iran, DARSI & - \\
\hline $\begin{array}{l}\text { T. aestivum cv. } \\
\text { Cross-Sabalan }\end{array}$ & Kermanshah & & & - & $\mathrm{AB}$ & bread wheat & Iran, DARI & - \\
\hline T. aestivum cv. Zagros & Kermanshah & & & - & $\mathrm{ABD}$ & bread wheat & Iran, DARI & - \\
\hline
\end{tabular}

DARSI - Dry Land Agricultural Research Sub-Institute, Sararood, Kermanshah; DARI - Dry Land Agricultural Research Institute, Iran

Table 2. Analysis of variance for studied traits of control cultivars

\begin{tabular}{|c|c|c|c|c|c|c|c|c|c|}
\hline \multirow[b]{2}{*}{$\begin{array}{l}\text { Source of } \\
\text { variation }\end{array}$} & \multirow[b]{2}{*}{$\begin{array}{l}\text { Degree } \\
\text { freedom }\end{array}$} & \multicolumn{8}{|c|}{ Mean of squares } \\
\hline & & spike length & awn length & $\begin{array}{l}\text { peduncle } \\
\text { length }\end{array}$ & $\begin{array}{l}\text { plant } \\
\text { height }\end{array}$ & $\begin{array}{l}\text { peduncle } \\
\text { length/ } \\
\text { plant height }\end{array}$ & $\begin{array}{l}\text { number of } \\
\text { spikelets } \\
\text { per spike }\end{array}$ & $\begin{array}{c}\text { number of } \\
\text { kernels } \\
\text { per spike }\end{array}$ & $\begin{array}{c}\text { thousand } \\
\text { kernel } \\
\text { weight }\end{array}$ \\
\hline Replication & 6 & 0.245 & 1.20 & 12.14 & 4.22 & 0.001 & 1.73 & 427.9 & 18.33 \\
\hline Cultivars & 5 & $14.38^{* *}$ & $80.60 * *$ & $444.79 * *$ & $982.07 * *$ & $0.008^{* *}$ & $12.12 * *$ & $1339.00 * *$ & $99.46 * *$ \\
\hline Error & 30 & 0.235 & 0.577 & 10.88 & 20.07 & 0.0006 & 0.96 & 225.64 & 23.48 \\
\hline $\mathrm{CV} \%$ & & 4.92 & 7.38 & 8.06 & 5.18 & 5.25 & 4.72 & 18.00 & 10.4 \\
\hline \multirow[b]{2}{*}{$\begin{array}{l}\text { Source of } \\
\text { variation }\end{array}$} & \multirow[b]{2}{*}{$\begin{array}{l}\text { Degree } \\
\text { freedom }\end{array}$} & \multicolumn{8}{|c|}{ Mean of squares } \\
\hline & & $\begin{array}{l}\text { days to } \\
\text { stem } \\
\text { elongation }\end{array}$ & $\begin{array}{l}\text { days to } \\
\text { booting }\end{array}$ & $\begin{array}{l}\text { days to } \\
\text { heading }\end{array}$ & $\begin{array}{l}\text { day } \\
\text { anth }\end{array}$ & $\begin{array}{l}\text { s to } \\
\text { esis }\end{array}$ & $\begin{array}{c}\text { days to } \\
\text { physiological } \\
\text { maturity }\end{array}$ & & $\begin{array}{l}\text { kernel } \\
\text { illing period }\end{array}$ \\
\hline Replication & 6 & 16.092 & 1.71 & 492.33 & 3. & 55 & 0.095 & & 2.76 \\
\hline Cultivars & 5 & 16.090 & $7.71 * *$ & 505.16 & 52.7 & $2 * *$ & $7.02 * *$ & & $49.23 * *$ \\
\hline Error & 30 & 16.095 & 1.71 & 464.33 & 2. & & 0.095 & & 2.30 \\
\hline $\mathrm{CV} \%$ & & 3.44 & 0.88 & 14.25 & 1. & 95 & 0.16 & & 5.63 \\
\hline
\end{tabular}

** - significant at $1 \%$ probability level

Mean comparison of Triticum boeoticum samples. Regarding the high number of the samples in this study, the samples with maximum and the minimum values of the traits were separated by $\overline{\mathrm{X}}+1.96 \delta \overline{\mathrm{X}}$ and $\bar{X}-1.96 \delta \bar{X}$ to have the limited number of the samples in both extremes. The data showing both extremes of the morphological and phenological traits in the populations along with the coefficient of variation $(\mathrm{CV})$ and least significant differences (LSD) are presented in Table 3. Spike length varied from 5.80 (I20) to16.90 (M3) $\mathrm{cm}$. 
Table 3. Mean of the studied traits in the samples of Triticum boeoticum

\begin{tabular}{|c|c|c|c|c|c|c|c|c|}
\hline & $\begin{array}{l}\text { Accessions codes } \\
(\overline{\mathrm{X}}-1.96 \delta \overline{\mathrm{X}})\end{array}$ & $\begin{array}{l}\text { Accessions codes } \\
(\bar{X}+1.96 \delta \bar{X})\end{array}$ & $\begin{array}{l}\text { Mean } \pm \text { SE } \\
(\mathrm{n}=252)\end{array}$ & Min & Max & $\begin{array}{l}\mathrm{CV} \\
\%\end{array}$ & $\begin{array}{l}\text { LSD } \\
5 \%\end{array}$ & $\begin{array}{l}\text { LSD } \\
1 \%\end{array}$ \\
\hline SL & $\mathrm{I} 20, \mathrm{I} 12, \mathrm{~J} 13, \mathrm{I} 3, \mathrm{I} 10$ & M3, G12, G14, P5, G13, P8 & $11.67 \pm 0.13$ & 5.80 & 16.90 & 4.92 & 1.442 & 1.941 \\
\hline $\mathrm{AL}$ & E7, E11, E3, E6, E9 & $\mathrm{H} 11, \mathrm{H} 7, \mathrm{H} 20, \mathrm{H} 1, \mathrm{H} 13$ & $8.31 \pm 0.12$ & 3.00 & & 7.38 & 2.283 & 3.075 \\
\hline NSPS & $\mathrm{I} 20, \mathrm{I} 3, \mathrm{I} 9, \mathrm{I} 8, \mathrm{D} 8$ & P9, P8, P1, P7,P5 & $29.41 \pm 0.25$ & 12.80 & 39.00 & 4.72 & 2.945 & 3.966 \\
\hline NKPS & C9, A9, C3, I20, A6 & $\mathrm{D} 3, \mathrm{P} 9, \mathrm{P} 1, \mathrm{P} 5, \mathrm{~T} 16$ & 53.0 & 16.80 & 108.80 & 18.00 & 45.150 & 60.805 \\
\hline PL & $\mathrm{R} 3, \mathrm{P} 2$ & G12, & 7 & 34. & 72 & 8.06 & 9.914 & 13.352 \\
\hline Phe & & G12 & & 98.40 & & 5.18 & 13.466 & 18.134 \\
\hline $\mathrm{PL} / \mathrm{Phe}$ & 98 & $\mathrm{I} 2$ & 02 & 0.30 & 0 . & 5.52 & 0.074 & 0.099 \\
\hline TKW & $\mathrm{K} 17, \mathrm{~J} 10$ & G5, G9, M1, G3, G6 & $15.17 \pm 0.14$ & 10.08 & 22.04 & 10.4 & 14.565 & 19.615 \\
\hline DB & $\mathrm{J} 2, \mathrm{C} 9, \mathrm{C} 7, \mathrm{I} 7, \mathrm{C} 1$ & G7, G12, G8, H4 & $162.48 \pm 0.37$ & 154.00 & 169.00 & 0.8 & 3.931 & 5.293 \\
\hline DA & $\mathrm{C} 7, \mathrm{I} 7, \mathrm{C} 10, \mathrm{I} 5, \mathrm{C} 3$ & $\mathrm{G} 7, \mathrm{G} 12, \mathrm{G} 8, \mathrm{H} 4$ & $177.49 \pm 0.22$ & 169.00 & & 1.05 & 5.154 & 6.941 \\
\hline DPM & & S20, P & & & & 0.16 & 0.926 & 1.248 \\
\hline KFP & $\mathrm{G} 7, \mathrm{G} 12, \mathrm{G} 8, \mathrm{H} 4$ & N15, S20, P8, K11, K13, K3 & $15.42 \pm 0.32$ & 9.00 & 30.00 & 5.63 & 4.558 & 6.139 \\
\hline
\end{tabular}

SL - spike length, cm, AL - awn length, cm, NSPS - number of spikelets per spike, NKPS - number of kernels per spike, PL peduncle length, $\mathrm{cm}$, Phe - plant height, cm, PL/Phe - peduncle length/plant height, TKW - thousand kernel weight, g, DB - days to booting, DA - days to anthesis, DPM - days to physiological maturity, KFP - kernel filling period

The shortest and the longest awn length were recorded for E7 $(3.00 \mathrm{~cm})$ and H11 $(14.50 \mathrm{~cm})$, respectively. Samples P9 and I20 with 39.00 and 12.80 had the maximum and the minimum values of number of spikelets per spike, respectively. Number of spikelets per spike ranged from 16.80 (I3) to 108.80 (D3). Peduncle length ranged from 34 (R3) to $72.40(\mathrm{G} 12) \mathrm{cm}$. The plant height ranged from $98.40(\mathrm{P} 2)$ to $153.70(\mathrm{G} 12) \mathrm{cm}$. The highest plant height was recorded for sample G12 $(153.70 \mathrm{~cm})$ followed by samples M1 $(152.50 \mathrm{~cm})$ and G5 $(148.00 \mathrm{~cm})$. The samples P2 $(98.40 \mathrm{~cm})$ and D9 $(98.60 \mathrm{~cm})$ had the shortest height. Thousand kernel weight was maximum in G5 sample by 22.04 gram and was minimum in F4, S8, K17, J10 - by 10-11 gram. The samples G7, G12, G8 and H4 had the highest phenological parameters such as days to booting and days to anthesis. The samples S20, P8, K11, K13 and K3 were the highest for days to physiological maturity and kernel filling period. Samples G7, G12, G8 and H4 were the lowest for days to physiological maturity and kernel filling period.

Analysis of variance between and within population of einkorn wheat. In order to find out the variation between and within the populations (classified based on geographical location), the analysis of variance was performed. The results showed that the variation between the populations was highly significant for all of the traits except the kernel filling period which means that the variation between the populations was significantly more than within the populations (Table 4). The percentage of the variation devoted to between the populations to total variation was the highest for days to booting and the lowest for kernel filling period and days to the physiological maturity.

Table 4. Analysis of variance between and within populations of einkorn wheat (Triticum boeoticum) for studied traits

\begin{tabular}{|c|c|c|c|c|c|c|c|c|}
\hline \multirow[b]{2}{*}{ Source of variation } & \multirow[b]{2}{*}{$\begin{array}{l}\text { Degree } \\
\text { freedom }\end{array}$} & \multicolumn{7}{|c|}{ Mean of squares } \\
\hline & & $\begin{array}{l}\text { spike } \\
\text { length }\end{array}$ & $\begin{array}{l}\text { awn } \\
\text { length }\end{array}$ & $\begin{array}{l}\text { peduncle } \\
\text { length }\end{array}$ & $\begin{array}{l}\text { plant } \\
\text { height }\end{array}$ & $\begin{array}{c}\text { peduncle } \\
\text { length/ } \\
\text { plant height }\end{array}$ & $\begin{array}{c}\text { number of } \\
\text { spikelets } \\
\text { per spike }\end{array}$ & $\begin{array}{c}\text { number of } \\
\text { kernels } \\
\text { per spike }\end{array}$ \\
\hline Between populations & 15 & $38.54 * *$ & $45.08 * *$ & $297.51 * *$ & $668.04 * *$ & $0.007 * *$ & $142.81 * *$ & $604.60 * *$ \\
\hline Within populations & 236 & 2.49 & 1.60 & 18.91 & 65.30 & 0.0006 & 8.79 & 129.05 \\
\hline \multirow[t]{2}{*}{$\begin{array}{l}\% \text { variation of between } \\
\text { population/total variation }\end{array}$} & - & 49.59 & 64.16 & 49.99 & 39.40 & 42.57 & 51.06 & 22.94 \\
\hline & & $\begin{array}{c}\text { thousand } \\
\text { kernel } \\
\text { weight }\end{array}$ & $\begin{array}{c}\text { days to } \\
\text { stem } \\
\text { elongation }\end{array}$ & $\begin{array}{l}\text { days to } \\
\text { booting }\end{array}$ & $\begin{array}{l}\text { days to } \\
\text { heading }\end{array}$ & $\begin{array}{l}\text { days to } \\
\text { anthesis }\end{array}$ & $\begin{array}{c}\text { days to } \\
\text { physiological } \\
\text { maturity }\end{array}$ & $\begin{array}{l}\text { kernel } \\
\text { filling } \\
\text { period }\end{array}$ \\
\hline Between populations & 15 & $48.83 * *$ & $501.91 * *$ & $453.42 * *$ & $376.19 * *$ & $138.74 * *$ & $157.66^{* *}$ & $42.53 \mathrm{~ns}$ \\
\hline Within populations & 236 & 2.86 & 16.36 & 8.15 & 54.99 & 4.60 & 26.00 & 25.78 \\
\hline $\begin{array}{l}\% \text { variation of between } \\
\text { population/total variation }\end{array}$ & - & 52.04 & 66.10 & 77.95 & 30.30 & 65.71 & 12.35 & 9.49 \\
\hline
\end{tabular}

**, ns - significant at $1 \%$ probability level and non significant, respectively

Correlation coefficients. The correlation coefficientsamongthetraits ofthe 252 accessionsareshown in Table 5. It should be noticed that the weaker correlations were significant due to the high number of the samples. Therefore, the correlations more than 0.5 are presented. SL had a high positive significant correlation with NSPS $\left(r=0.882^{* *}\right)$, DSE $\left(r=0.560^{* *}\right)$, DB $\left(r=0.595^{* *}\right)$ and DA $\left(r=0.528^{* *}\right)$. There was a significant and positive correlation between NSPS and NKPS $\left(r=0.544^{* *}\right)$, DSE $\left(r=0.600^{* *}\right)$, DB $\left(r=0.628^{* *}\right)$ and DA $\left(r=0.547^{* *}\right)$. PL had high significant and positive correlations with Phe $\left(r=0.766^{* *}\right)$, PL/PLH $\left(r=0.605^{* *}\right)$ and TKW $\left(r=0.540^{* *}\right)$. DSE was significantly correlated with DB $\left(r=0.882^{* *}\right)$, DH $\left(r=0.882^{* *}\right)$ and DA $\left(r=0.882^{* *}\right)$. The correlation between DPM and KFP was positive and highly significant $(r=0.797 * *)$. 
Table 5. Correlation coefficients between the studied traits $(\mathrm{n}=252)$ of Triticum boeoticum

\begin{tabular}{|c|c|c|c|c|c|c|c|c|c|c|c|c|c|c|}
\hline & SL & $\mathrm{AL}$ & NSPS & NKPS & PL & Phe & PL/Phe & TKW & DSE & DB & DH & DA & DPM & KFP \\
\hline $\mathrm{SL}$ & 1 & & & & & & & & & & & & & \\
\hline $\mathrm{AL}$ & 0.121 & 1 & & & & & & & & & & & & \\
\hline NSPS & $0.882 * *$ & -0.014 & 1 & & & & & & & & & & & \\
\hline NKPS & $0.482 * *$ & -0.002 & $0.544 * *$ & 1 & & & & & & & & & & \\
\hline PL & $-0.323 * *$ & 0.032 & $-0.407^{* *}$ & $-0.137^{*}$ & 1 & & & & & & & & & \\
\hline Phe & -0.097 & 0.012 & $-0.154 *$ & -0.002 & $0.766^{* *}$ & 1 & & & & & & & & \\
\hline $\mathrm{PL} / \mathrm{Phe}$ & $-0.373 * *$ & 0.043 & $-0.433 * *$ & $-0.201 * *$ & $0.605^{* *}$ & -0.043 & 1 & & & & & & & \\
\hline TKW & $-0.136^{*}$ & $0.281 * *$ & $-0.279 * *$ & $-0.125^{*}$ & $0.540 * *$ & $0.419 * *$ & $0.333 * *$ & 1 & & & & & & \\
\hline DSE & $0.560 * *$ & -0.069 & $0.600 * *$ & $0.345^{* *}$ & $-0.392 * *$ & $-0.156^{*}$ & $-0.407^{* *}$ & $-0.262 * *$ & 1 & & & & & \\
\hline DB & $0.595 * *$ & -0.118 & $0.628^{* *}$ & $0.321^{* *}$ & $-0.419^{* *}$ & $-0.192 * *$ & $-0.407 * *$ & $-0.293^{* *}$ & $0.858^{* *}$ & 1 & & & & \\
\hline DH & $0.347 * *$ & -0.029 & $0.401 * *$ & $0.243^{* *}$ & $-0.273 * *$ & -0.093 & $-0.313^{* *}$ & $-0.225^{* *}$ & $0.570^{* *}$ & $0.668^{* *}$ & 1 & & & \\
\hline DA & $0.528 * *$ & -0.111 & $0.574 * *$ & $0.331 * *$ & $-0.388 * *$ & $-0.219^{* *}$ & $-0.331 * *$ & $-0.309^{* *}$ & $0.746^{* *}$ & $0.846^{* *}$ & $0.531^{* *}$ & 1 & & \\
\hline DPM & $0.317 * *$ & -0.118 & $0.314 * *$ & 0.082 & $-0.440 * *$ & $-0.384 * *$ & $-0.211 * *$ & $-0.205^{* *}$ & $0.444^{* * *}$ & $0.477 * *$ & $0.223^{* *}$ & $0.477 * *$ & 1 & \\
\hline $\mathrm{KFP}$ & -0.006 & -0.056 & -0.041 & $-0.136^{*}$ & $-0.228^{* *}$ & $-0.281 * *$ & -0.011 & -0.018 & -0.012 & -0.045 & -0.114 & $-0.150 *$ & $0.797 * *$ & 1 \\
\hline
\end{tabular}

SL - spike length, AL - awn length, NSPS - number of spikelets per spike, NKPS - number of kernels per spike, PL - peduncle length, Phe - plant height, PL/Phe - peduncle length/plant height, TKW - thousand kernel weight, DSE - days to stem elongation, DB - days to booting, DH - days to heading, DA - days to anthesis, DPM - days to physiological maturity, KFP - kernel filling period; $* *, *$ significant at $1 \%$ and $5 \%$ probability level, respectively

Cluster analysis. Cluster analysis grouped accessions into five clusters based on the measured traits (Fig. 2). Each cluster consists of accessions collected from different geographical locations.

The results of this analysis revealed high diversity among the studied accessions. The first group included 86 accessions. The accessions in this group were low for Phe, TKW and KFP (Table 6). The values of the traits such as AL, SL, NKPS, NSPS and other phenological traits were varied from moderate to high. The second group included 48 accessions. They averagely had the highest SL, NSPS and all the phenological traits but they had the lowest AL and TKW. Therefore, the accessions in this group are late-matured accessions. In the third group, 72 accessions had the moderate values of the traits, including SL, AL, NSPS, NKPS and the

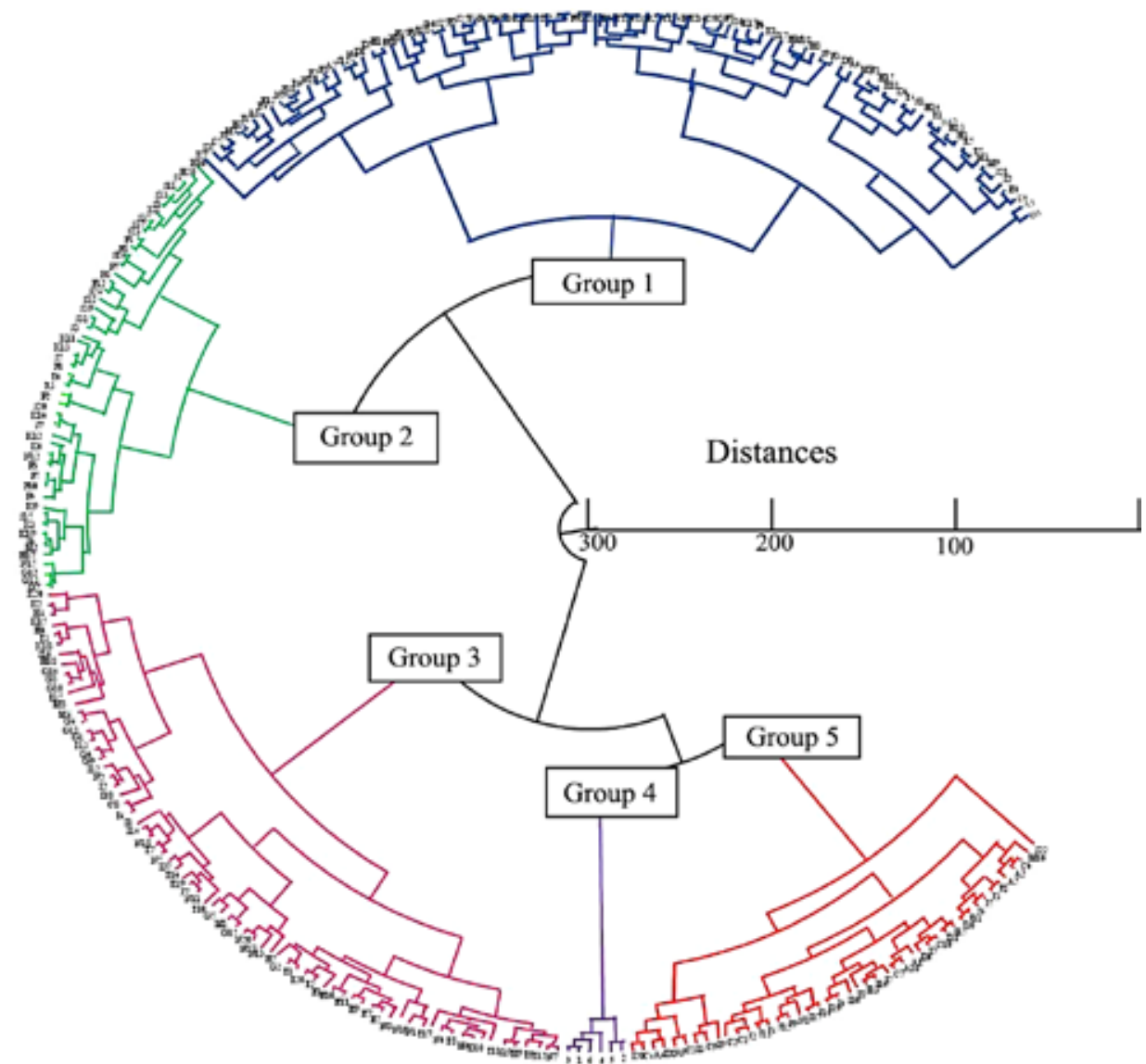

Figure 2. Dendrogram of the Triticum boeoticum samples performed based on the studied agronomical traits using Ward method 
Table 6. The mean of groups obtained by the cluster analysis for 252 accessions of Triticum boeoticum and 6 durum and bread wheat cultivars based on 13 different traits

\begin{tabular}{|c|c|c|c|c|c|c|}
\hline $\begin{array}{ll}\text { Trait } & \text { Cluster } \\
\end{array}$ & Group1 & Group2 & Group3 & Group4 & Group5 & Total mean \\
\hline $\mathrm{SL}$ & 12.33 & 13.02 & 11.43 & 9.84 & 9.41 & 11.63 \\
\hline $\mathrm{AL}$ & 8.35 & 7.85 & 8.20 & 10.29 & 8.87 & 8.35 \\
\hline NSPS & 31.20 & 31.93 & 28.72 & 20.81 & 24.50 & 29.21 \\
\hline NKPS & 56.99 & 54.70 & 54.69 & 83.43 & 41.63 & 53.80 \\
\hline PL & 54.85 & 52.39 & 62.95 & 40.90 & 60.03 & 57.25 \\
\hline Phe & 118.09 & 114.34 & 133.58 & 86.40 & 120.85 & 121.47 \\
\hline TKW & 14.38 & 14.10 & 16.18 & 46.17 & 16.20 & 15.90 \\
\hline DSE & 156.72 & 159.21 & 153.07 & 116.62 & 146.20 & 153.36 \\
\hline DB & 164.59 & 168.17 & 161.26 & 148.43 & 154.48 & 162.15 \\
\hline $\mathrm{DH}$ & 172.29 & 175.42 & 169.06 & 151.17 & 159.33 & 169.17 \\
\hline DA & 178.59 & 180.79 & 176.74 & 162.33 & 173.17 & 177.14 \\
\hline DPM & 190.29 & 204.29 & 190.07 & 189.29 & 190.41 & 192.83 \\
\hline KFP & 11.70 & 23.50 & 13.33 & 26.95 & 17.24 & 15.69 \\
\hline
\end{tabular}

SL - spike length, cm, AL - awn length, cm, NSPS - number of spikelets per spike, NKPS - number of kernels per spike, PL peduncle length, $\mathrm{cm}$, Phe - plant height, $\mathrm{cm}$, TKW - thousand kernel weight, g, DSE - days to stem elongation, DB - days to booting, DH - days to heading, DA - days to anthesis, DPM - days to physiological maturity, KFP - kernel filling period

phenological traits. These accessions had averagely the highest PL and Phe. The fourth group contained only 6 control cultivars. The minimum NSPS, Phe, PL and all phenological traits were recorded for this group. The accessions in this cluster had short life cycle; therefore they are early-matured accessions. These accessions had the highest AL, NKPS, TKW and KFP. The last group contained 46 accessions. The minimum SL and NKPS were recorded for this group. These accessions had the lowest SL and NKPS with moderate PL, TKW and KFP.

The analysis of variance was carried out according to the five groups obtained from the cluster analysis for 252 accessions and control cultivars (Table 7). The results indicated that the variation between the groups for the most of the traits was less than within the groups when compared to all found variation.

Table 7. Analysis of variance according to five groups obtained from cluster analysis for 252 accessions of Triticum boeoticum and control cultivars

\begin{tabular}{lcccccccccccccc}
\hline \multicolumn{1}{c}{ Source of } & Degree & \multicolumn{11}{c}{ Mean of squares } \\
\cline { 3 - 14 } $\begin{array}{l}\text { variation } \\
\text { freedom }\end{array}$ & SL & AL & PL & Phe & NSPS & NKPS & TKW & DSE & DB & DH & DA & DPM & KFP \\
Within groups & 85 & 3.4 & 4.1 & 24.3 & 72.0 & 12.2 & 176.5 & 19.5 & 44.5 & 46.9 & 54.3 & 12.8 & 9.3 & 24.9 \\
\hline $\begin{array}{l}\text { \% variation of } \\
\text { between groups/ } \\
\text { total variation }\end{array}$ & 172 & 5.3 & 4.6 & 51.3 & 160.2 & 21.1 & 179.5 & 31.7 & 92.5 & 21.4 & 95.1 & 20.1 & 45.3 & 31.5 \\
\hline
\end{tabular}

SL - spike length, AL - awn length, PL - peduncle length, Phe - plant height, NSPS - number of spikelets per spike, NKPS number of kernels per spike, TKW - thousand kernel weight, DSE - days to stem elongation, DB - days to booting, DH - days to heading, DA - days to anthesis, DPM - days to physiological maturity, KFP - kernel filling period

For example, $37.6 \%$ of total variation in TKW is due to the variation found between the groups. This shows that the accessions within the groups are different from each other.

\section{Discussion}

The existence of high significant genotypic differences among the materials studied in this research indicated that there is a high variation among them. Moghaddam et al. (2012) and Pour-Aboughadareh et al. (2012) observed high significant differences among einkorn wheat based on agro-morphological traits which indicated the high genetic variation among samples. Besides, Naghavi et al. (2009) reported high variation among T. boeoticum populations collected from northwest to south western parts of Iran. Malaki et al. (2006) assessed the genetic diversity of $T$. boeoticum from the western part of Iran and observed high diversity in these species.

High thousand kernel weight of samples G5 could be due to the high plant height and the peduncle length. Thus, this result indicated the importance of spike in the dry matter remobilization. On the other hand, the high remobilization rate of internodes of stem showed that this could be due to their potential in reservation of photosynthesis materials especially before the flowering stage (Ehdaie et al., 2006).

At the present study, there was a significant and positive correlation between Phe and TKW which is in accordance with Moghaddam et al. (2012) on T. boeoticum populations. The significant and positive correlation between grain yield and plant height was reported in Iranian wild spontaneum barely (Afzalifar et al., 2011). In contrast, Nabovati et al. (2010) and Naghdipour et al. (2011) reported significant and negative correlation between these two traits. Calderini et al. (1995) stated that the improvement of the grain yield has been achieved in modern wheat cultivars through the reduction of the plant height; since, the transfer of the materials to reproduction part has grown compared to the vegetative part without the basic change in biomass. Ehdaie and Waines (1989) found out that the plant height had a negative genetic correlation with the number of grains per head, 1000-grain weight, grain yield and harvest index.

Moreover, in this research, it was found out that the genetic correlation between the number of heads per plant and the number of grains per head, 1000-grain weight and harvest index was also significantly negative. The harvest index had a negative genetic correlation with 
the days to booting, to maturity, plant height, number of heads per plant and straw yield, and a positive correlation with the number of grains per head, 1000-grain weight and grain yield. In investigating of 298 wheat landraces by Masood et al. (2005) a high positive significant correlation among days to heading, days to physiological maturity, plant height and the number of spikelets per spike were observed. Thousand kernel weight will increase by the increase of the peduncle length due to the dry matter remobilization during the kernel filling period. Al-Karaki (2012) also reported a significant and positive correlation between these two traits. Moreover, there was a significant and negative correlation between NKPS and TKW which is in accordance with many other studies (Mohammed et al., 2001). It can be stated that by increasing the number of grains per spike, availability of assimilates for grain becomes less and thus leads to a decrease in the grain weight. Naroui Rad et al. (2007) studied the genetic variation of the wheat native accessions of Sistan and Baluchistan province and reported that there is a positive and significant correlation between the grain yield and the number of days to spike appearance, spike length, 100 seed weight, number of tillers, and height stem width, number of spikelets in spike and the grain number per spike.

Overall, taking advantage of this genetic variation in wheat breeding programs is necessary. In this study, the wild accessions generally were taller, longer spike length, longer peduncle length, more number of spikelets per spike and longer life cycle with shorter awn, lower thousand kernel weight, less number of kernels per spike and short kernel filling period when compared to the control cultivars.

Ehdaie and Waines (1989) compared the local lines and the improved wheat cultivars and reported that although, the local lines were taller and produced a larger number of non-effective tillers, the mean number of grains per head, grain weight, harvest index and grain yield of them were less than those of the improved cultivars. Their observations indicated that the landraces could be improved by selecting the shorter accessions with the lower number of tillers per plant, but with the higher number of grains per head and heavier grains.

Regarding the high variation of $T$. boeoticum accessions in the central Zagros Mountains we would like to orient the attentions towards these germplasm. In this study, the population $\mathrm{G}$ collected from Kamyaran location (Table 1) was recognized as desirable germplasm based on the most of the studied traits.

The traits recorded are very important for clustering wheat genetic resources which are essential and helpful for the breeders seeking to improve the existing germplasm by introducing novel genetic variation for certain traits into the breeding populations (Salem et al., 2008; Pagnotta et al., 2009; Zarkti et al., 2010).

Therefore, these traits have a good potential in order to select and to conserve populations. Further investigations are being conducted on the variation of the samples for the percentage of the protein, the concentration of important micronutrients especially zinc and iron, resistance to biotic and abiotic stresses such as rust and drought stresses.

\section{Conclusions}

The following conclusions were drawn from this study regarding the high variation of Triticum boeoticum accessions as wheat wild relatives in the west province of Iran are:
1. The population $\mathrm{G}$ collected from Kamyaran location showed higher values than average for the spike length, peduncle length, plant height and thousand kernel weight.

2. Variation among populations (each population taken from a location) was significantly higher than that within the populations showing that the difference between the accessions in each location was negligible.

3 . The cluster analysis classified the accessions into five clusters based on the measured traits. All the control cultivars were categorized in one cluster. The classification of accessions using the cluster analysis did not match with the geographical distribution.

4. These accessions with diverse morphological characters contributing to the genetic diversity could be considered important gene pool with distinct features for cultivar development.

\section{Acknowledgements}

We wish to thank the authorities of Razi University for providing the financial support for field experimentation as M.Sc. thesis. We thank to Dr. N. Hooti Associate Professor in dramatic literature in Razi University for English language editing and M. M. Poursiahbidi for providing samples of this study. We would like to acknowledge R. Amiri for his help in statistical analysis.

Received 12062016 Accepted 21112016

\section{References}

Afzalifar A., Zahravi M., Bihamta M. R. 2011. Evaluation of tolerant genotypes to drought stress in Karaj region. Journal of Agronomy and Plant Breeding, 7: 25-44

Al-Karaki G. N. 2012. Phenological development-yield relationships in durum wheat cultivars under late-season high-temperature stress in a semiarid environment. International Scholarly Research Notices: ISRNAgronomy, 2012: 7 https://doi.org/10.5402/2012/456856

Calderini D. F., Dreccer M. F. Slafer G. A. 1995. Genetic improvement in wheat yield and associated traits. A re-examination of previous results and the latest trends. Plant Breeding. 114 (2): 108-112 https://doi.org/10.1111/j.1439-0523.1995.tb00772.x

Ciafti M., Dominici L., Latiandra D., Porceddu E. 1992. Seed storage protein of wild wheat progenitors and their relationships with technological properties. Hereditas, 116: $315-322$ https://doi.org/10.1111/j.1601-5223.1992.tb00844.x

Dempewolt H., Eastwood K. J., Guarino L., Khoury C. K., Müller J. V., Toll J. 2014. Adapting agriculture to climate change: a global initiative to collect, conserve, and use crop wild relatives. Agroecology and Sustainable Food Svstems. 38 (4): 369-377 https://doi.org/10.1080/21683565.2013.870629

Derakhshani B., Mohammadi S. A., Moghaddam M., Jalal Kamali M. R. 2013. Allelic variation of VRN-1 locus in Iranian wheat landraces. Journal of Plant Physiology and Breeding, 3 (1): 45-56

Ehdaie B., Waines J. G. 1989. Genetic variation, heritability and path-analysis in landraces of bread wheat from southwestern Iran. Euphytica, 41 (3): 183-190

Ehdaie B., Alloush G. A., Madore M. A., Waines J. G. 2006. Genotypic variation for stem reserves and mobilization in wheat post-anthesis changes in internodes dry matter. Cron Science. 46: 735-746 https://doi.org/10.2135/cropsci2005.04-0033

Gill B. S., Appels R., Botha-Oberholster A. M., Buell C. R. Bennetzen J. L., Chalhoub B., Chumley F., Dvorak J., Iwanaga M., Keller B. 2004. A workshop report on wheat genome sequencing: international genome research on wheat consortium. Genetics, 168: 1087-1096 https://doi.org/10.1534/genetics.104.034769 
Guarino L., Lobell D. B. 2011. A walk on the wild side. Nature Climate Change. 1: 374-375 https://doi.org/10.1038/nclimate 1272

Harlan J. R., Zohary D. 1966. Distribution of wild wheats and barley. Science, 153: 1074-1080 https://doi.org/10.1126/science.153.3740.1074

Kimber G., Feldman M. 1987. Wild wheat: an introduction. Special Report No. 353, 146 p.

Lilienfeld F., Kihara H. 1934. Genome analysis Triticum and Aegilops. Triticum timofeev Zhuk. Cytologia, 6: 87-122

Malaki M., Naghavi M. R., Alizadeh H., Potki P., Kazemi M., Pirseyedi S. M., Mardi M., Tabatabaei F. 2006. Study of genetic variation in wild diploid wheat (Triticum boeoticum) from Iran using AFLP markers. Iranian Journal of Biotechnology, 4: 269-274

Masood M. S., Javaid A., Rabbani M. A., Anwar R. 2005. Phenotypic diversity and trait association in bread wheat (Triticum aestivum L.) landraces from Baluchistan, Pakistan. Pakistan Journal of Botany, 37 (4): 949-958 http://www.pakbs.org/pjbot/PDFs/37(4)/PJB37(4)0949.pdf

Moghaddam M., Mazinani M. A., Alavinia S. S., Shakiba M. R., Mehrabi A., Pour-Aboughadareh A. 2012. Study of genetic diversity in T.boeoticum populations under normal and water deficit stress conditions. Cereal Research, 2 (1): 17-30 (in Farsi)

Mohammed B., Lutts S., Kinet J. J. 2001. Water deficit effects on solute contribution to osmotic adjustment as a function of leaf ageing in three durum wheat (Triticum turgidum) cultivars performing differently in arid conditions. Plant Science. 160: 669-981 https://doi.org/10.1016/S0168-9452(00)00443-X

Nabovati S., Aghaee Sarbarzeh M., Choukan R., Ghanavati F., Najafian G. 2010. Genetic variation in agronomic characteristics and grain quality traits of durum wheat genotypes. Seed and Plant Improvement Journal, 26: 331350 (in Farsi)

Naghavi M. R., Maleki M., Tabatabaei S. F. 2009. Efficiency of floristic and molecular markers to determine diversity in Iranian populations of $T$. boeoticum. International Journal of Biological, Biomolecular, Agricultural, Food and Biotechnological Engineering, 3 (1): 36-38

Naghdipour A., Khodarahmi M., Pourshahbazi A., Esmailzade M. 2011. Factor analysis for grain yield and other traits in durum wheat. Iranian Journal of Agronomy and Plant Breeding, 7: 84-89

Naroui Rad M. R., Farzanju M., Fanaei H. R., Arjmandy Nejad A. R., Ghasemy A., Polshekane Pahlevan M. R. 2007. The study genetic variation and factor analysis for morphological characters of wheat native accessions of Sistan and Baluchistan. Pajouhesh and Sazandegi, 73: 50-57 (in Farsi)

Pagnotta M. A., Mondini L., Codianni P., Fares C. 2009. Agronomical, quality, and molecular characterization of twenty Italian emmer wheat (Triticum dicoccon) accessions. Genetic Resources and Crop Evolution, 56: 299-310 https://doi.org/10.1007/s10722-008-9364-4

Plucknett D. L., Smith N. J. H., Williams J. T., Anishetty N. M. 1987. Gene banks and the world's food. Princeton, USA

Pour-Aboughadareh A., Moghaddam M., Alavi-Kia S. S., Mehrabi A. A., Mazinani M. A. 2012. Evaluation of genetic diversity in some einkorn wheat (Triticum boeoticum) populations from Iran. $12^{\text {th }}$ Congress of Iranian Genetics Society, 1-5 (in Farsi)

Salem K. F. M., El-Zanaty A. M., Esmail R. M. 2008. Assessing wheat (Triticum aestivum L.) genetic diversity using morphological characters and microsatellite markers. World Journal of Agriculture Science, 4: 538-544

Salimi A., Ebrahimzadeh H., Taeb M. 2005. Description of Iranian diploid wheat resources. Genetic Resources and Crop Evolution. 52: 351-361 https://doi.org/10.1007/s10722-005-2256-y

Valkoun J. J. 2001. Wheat pre-breeding using wild progenitors. Euphvtica. 119: 17-23 https://doi.org/10.1023/A:1017562909881

Zarkti H., Ouabbou H., Hilali A., Udupa S. M. 2010. Detection of genetic diversity in Moroccan durum wheat accessions using agro morphological traits and microsatellite markers. African Journal of Agricultural Research, 5 (14): 1837-1844

ISSN 1392-3196 / e-ISSN 2335-8947

Zemdirbyste-Agriculture, vol. 104, No. 1 (2017), p. 23-30

DOI $10.13080 /$ z-a.2017.104.004

\title{
Zagros centrinio kalnyno laukinių vienagrūdžių kviečių genetinè įvairovè
}

\author{
B. Seifolahpour, S. Bahraminejad, K. Cheghamirza \\ Razi universitetas, Iranas
}

\section{Santrauka}

Genetiniai ištekliai yra nacionalinis kiekvienos šalies turtas. Kviečių laukiniai ekotipai, ypač diploidinès rūšys, turi kviečiu selekcijai naudingų požymių. Siekiant ištirti Irano Zagros centriniame kalnyne augančiu laukiniu vienagrūdžių kviečių (Triticum boeoticum Boiss.) populiaciju genetinę ìvairovę pagal jų morfologinius, agronominius ir fenologinius požymius, buvo surinkti ir ištirti 252 šiu kviečiu pavyzdžiai. Tyrimas atliktas 2013$2014 \mathrm{~m}$. Irane, Razi universito bandymu stotyje. Palyginimui kaip kontrolinis variantas dar buvo tirtos 3 paprastuju ir 3 kietujų kviečių veislès. Genotipų ir kontrolinių veislių sèklos buvo pasètos rendomizuotų pakartojimų blokais, 7 pakartojimais.

Dispersinè analizè parodè didelę variacija tarp genotipu. Populiacijos G, surinktos Kamyaran vietoveje, varpos ilgis, žiedynkočio ilgis, augalo aukštis ir tūkstančio grūdų masė buvo didesni nei populiacijų vidutiniai rodikliai. Koreliacijos rezultatai parodè, kad tūkstančio grūdų masè esmingai koreliavo su žiedynkočio ilgiu, augalo aukščiu ir akuotų ilgiu.

Pagal klasterine analize genotipai ir kontroliniai augalai, atsižvelgus i ju savybes, buvo suskirstyti penkias grupes. Genotipų klasifikavimas taikant klasterinę analizę neatitiko jų geografinio paplitimo. Pirmosios grupès genotipai pasižymèjo trumpesniu grūdo pildymosi laikotarpiu, antrosios - vèlyva branda, trečiosios - didžiausiu žiedynkočio ilgiu ir augalų aukščiu, ketvirtosios grupès genotipai buvo ankstyvos brandos ir pasižymėjo mažiausiu augalu aukščiu bei žiedynkočių ilgiu, penktosios - mažiausiu grūdų skaičiumi varpoje ir varpos ilgiu.

Reikšminiai žodžiai: genetiniai ištekliai, laukiniai ekotipai, papildytas modelis. 